\title{
Fen Bilimleri Öğretmen Adaylarının Derste Teknoloji Kullanımına Yönelik Eğilimleri ${ }^{1}$
}

\section{Pre-Service Science Teachers' Tendencies towards Using Technology in Class}

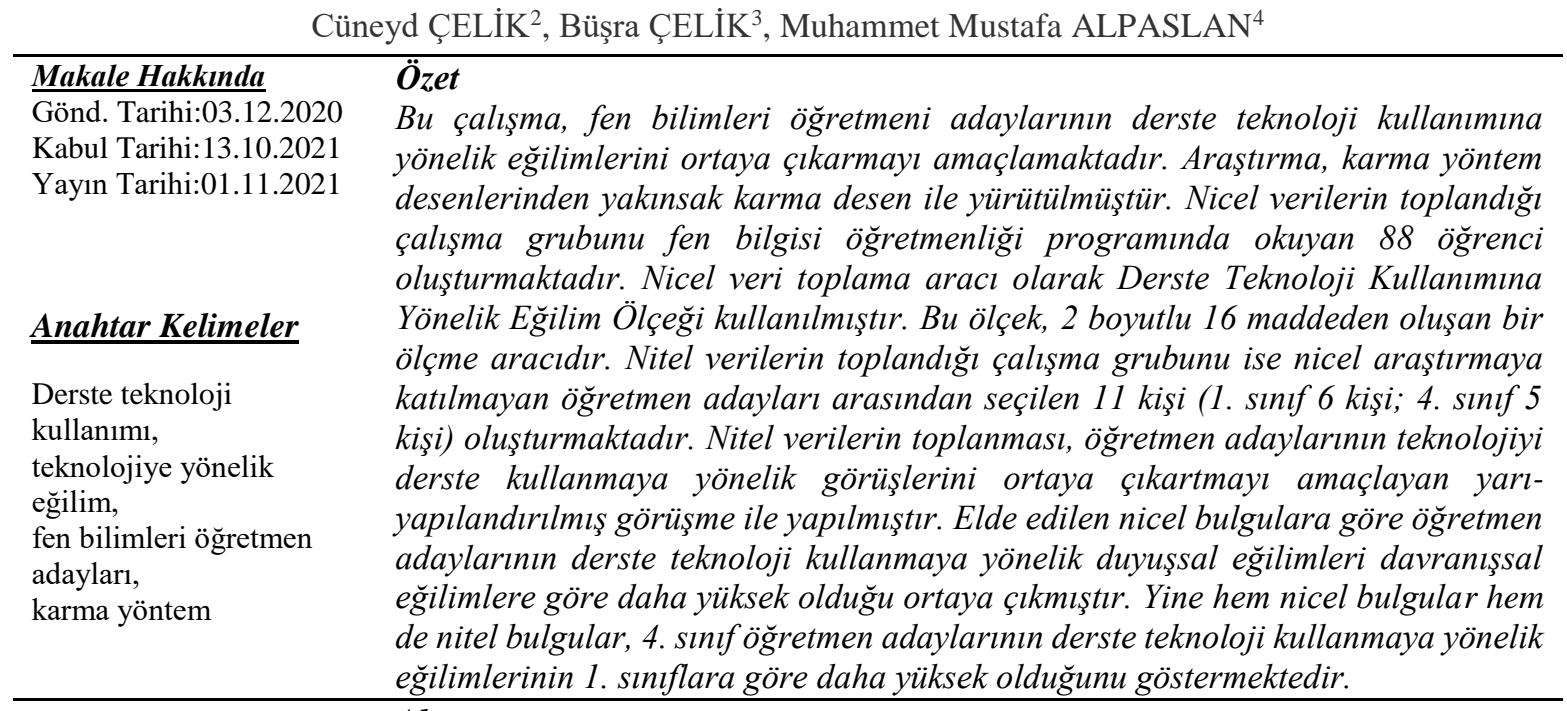

\section{$\underline{\text { Key Word }}$}

Use of technology in class, tendency towards technology, pre-service science teachers, mixed method

\section{Abstract}

The current study aimed to reveal the pre-service science teachers' tendencies towards using technology in class. The study employed the convergent mixed design, one of the mixed method designs. A total of 88 preservice teachers participated in the quantitative part of the study. As the data collection tool, the Scale of Tendency Towards Using Technology in Class was used. It consists of 16 items in two dimensions. A total of non-participant eleven preservice teachers volunteered to participate in the qualitative data collection part of the study (6 firstyear students and 5 fourth-year students). The qualitative data were collected with a semi-structured interview form constructed to elicit the participants' opinions about the use of technology in class. The quantitative findings revealed that preservice teachers' emotional tendency to use technology during lessons is higher than their behavioral tendencies. However, both quantitative and qualitative findings show that senior year preservice teachers' tendencies to use technology during lessons are higher than that of freshman year preservice teachers.

\begin{tabular}{ll}
\hline Atıf için: & Çelik, C., Çelik, B. \& Alpaslan, M.M. (2021). Fen bilimleri öğretmen adaylarının \\
& derste teknoloji kullanımına yönelik eğilimleri. Muğla Sitkı Koçman Üniversitesi \\
For Citation & Eğitim Fakültesi Dergisi [MSKU Journal of Education], 8(2), 503- 519. DOI: \\
& $10.21666 /$ muefd.835314.
\end{tabular}

\footnotetext{
1 Bu çalışma, 23-27 Ekim 2019 tarihinde 2. Uluslararası Temel Eğitim Kongresi’nde sözlü bildiri olarak sunulmuştur.

${ }^{2}$ Muğla Sitkı Koçman Üni., Eğitim Fakültesi, cuneydcelik@mu.edu.tr, ORCID: 0000-0002-1188-6260

${ }^{3}$ Muğla Sıtk1 Koçman Üni., Eğitim Bil. Enst., busraguney3510@ gmail.com, ORCID: 0000-0003-4026-1486 ${ }^{4}$ Muğla Sitkı Koçman Üni., Eğitim Fakültesi, mustafaalpaslan@mu.edu.tr,ORCID: 0000-0003-4222-7468
} 
Başlangıcı ateşin, tekerleğin ve yazının bulunmasıyla başlayan teknoloji serüveni, zamanla ihtiyaçların artması ve bilimsel bilginin birikerek çoğalmasıyla birlikte dönemsel olarak sürekli değişerek ve ilerleyerek günümüze kadar süre gelmiştir. Günümüzde de insanoğlunun yaşamından bağımsız olması beklenmeyecek bir duruma ulaşmıştır. Zira insanoğlu, teknolojinin herhangi bir ürününden faydalanmadan geçirdiği tek bir gün olmadığı düşünülmektedir (Ceylan ve Akçay, 2018). Bu bakımdan bilimsel faaliyetlerin bir ürünü olan ve insanların hayatını kolaylaştıran teknoloji, bugün yaşamın her alanında etkisini fazlasıyla hissettirmektedir.

Teknolojinin ilerlemesiyle içinde bulunduğumuz bu dönemde yeni bilginin ortaya çıkması neredeyse 1şık hızıyla yarışmaktadır. Özellikle 70'li yıllardan itibaren yeni bilgilerin üretilmesi ve işletilmesinde çeşitli araçlar ve yöntemler geliştirilmiştir. Diğer bir ifade ile elektronik ve bilgi teknolojilerinin yaygınlaşmaya başladığı 1970'li yıllar, üçüncü sanayi devriminin başlangıcı olarak kabul edilmektedir (Öğretir Özçelik, 2018). Zamanla elde edilen yeni bilgiler teknolojiyi, yeni teknolojilerde yeni bilgilerin elde edilmesini sağlamıştır. Bu karşı1ıklı katkılar sanayiden sağlığa, iletişimden ulaşıma kadar pek çok alanda avantajlar sağlamaktadır. Eğitim teknolojileri de bu katkıların yaşandığı bir diğer alan olarak gösterilebilir. Mobil uygulamalar, artırılmış ve sanal gerçeklik, robotik ve kodlama, animasyonlar, simülasyonlar ve Web 2.0 uygulamaları gibi pek çok eğitim teknolojileri eğitim-öğretim alanında öğrencilere önemli katkılar sağlamaktadır (Çelik, Güven, Çakır, 2020; Güven, Çakır, Sülün, Çetin \& Güven, 2020).

Eğitim teknolojileri, öğrenme ortamlarını ilgi çekici hale getirme, daha fazla duyuya hitap etmesine bağlı olarak kalıcılığı arttırma, soyut kavramları somut hale getirme ve gözlenmesi zor veya tehlikeli durumların öğretimini kolaylaştırmasından dolayı öğretimde kullanılması kaçınılmaz hale gelmiştir (Wojciechowski ve Cellary, 2013; Y1lmaz ve Batd1, 2016). Zira fen bilimleri derslerinde yer alan baz1 konular (DNA, atomun yapısı, molekül, uzay, duyu organları, manyetik alan vb.) (MEB, 2018b) çeşitli teknolojik cihazlar ya da programlarla desteklenmediği takdirde öğretmen adayları veya öğrencilerin zihinlerinde de soyut kalmaktadır (Pekdağ, 2010; Aslan Efe, Oral, Efe ve Öner Sünkür, 2011).

Eğitimde teknoloji kullanımı öğrencilerin bilim ve teknolojide yaşanan hızlı değişimlere uyum sağlamaları, teknoloji kullanımına alışmaları ve eğitim-öğretim sürecine alt yapı oluşturmak açısından da önemlidir (Kenar ve Balcı, 2013). Zira bireylerin yalnızca okuyarak kitaptan bilgiyi edinmesi veya sadece öğretmen merkezli yöntemlerle bilgiye ulaşması, teknoloji destekli öğretim karşısında oldukça etkisiz kalmaktadır. Diğer taraftan sunuş yöntemine nazaran görsel ve işitsel medya araçları kullanılarak gerçekleştirilen öğretim, öğrencilerin fen dersine yönelik tutumu ve başarısı üzerinde daha etkili olduğu belirlenmiştir. Bu bağlamda eğitimde teknoloji kullanımına odaklanılmıştır (Demirci Güler ve Irmak, 2018; Asan ve Haliloğlu, 2005; Özmen ve Kolomuç, 2004). Teknolojinin eğitime sağladığı önemli katkılardan dolayı ülkemiz genelinde de önemli adımlar atılmaya çalışılmaktadır. 2023 Eğitim Vizyonu kapsamında ulusal eğitim politikalarında derslerin dijital içerik yönünden zenginleşmesi yönünde adımlar atılmaya başlandığı görülmektedir (MEB, 2018a). 2018 fen bilimleri öğretim programının hedefleri doğrultusunda da dijital yetkinlik ve yenilikçi düşünme gibi yeterliliklerin kazandırılması hedeflenmektedir.

Bir diğer açıdan bakıldığında z-kuşağını oluşturan günümüz öğrencileri Google kuşağı, kristal nesil, internet kuşağı, gibi birçok isim ile anılmaktadır (Çetin ve Karalar, 2016). Bu nesil, yenilikçi teknolojilere ve teknolojinin hızlı gelişimine oldukça yakından takip etmektedir. Onların bu özellikleri, günlük yaşamlarında teknoloji ile iç içe yaşamalarına ve teknolojiyi devamlı kullanmalarına dayanmaktadır. $\mathrm{Bu}$ sebepten öğrenim görülen ortamlarında onların ilgilerini çekecek, öğretim sürecinden beklediği istek ve ihtiyaçlarına göre düzenlenmesi gerektiği savunulmaktadır (Kolikant, 2010). Buna karşın eğitim ortamlarının, öğrencilerin istek ve ihtiyaçlarına göre düzenlenmemesi ve teknolojinin bu anlamda eğitim ortamlarına etkili bir şekilde entegre edilememesi okullara karşı ilginin azalmasına neden olmaktadır. Buna bağlı olarak derslerin öğrenciler açısından sıkıcı geçmesi, derslere karşı ilginin azalmasını beraberinde getirebilmektedir (Pedro, 2006; Yazzie-Mintz, 2010).

Eğitimde teknoloji kullanımı birçok araştırmaya konu olmuştur. Bazı çalışmalar teknoloji kullanımının farklı değişkenler üzerine etkisi (Başarı, tutum, vb.) öğretmen adaylarının teknoloji kullanımına yönelik yeterlileri ve öğretmenlerin veya öğretmen adaylarının derslerinde teknoloji kullanmalarına yönelik eğilimleri üzerine yoğunlaştığı görülmektedir (Yenice, Candarlı Arıkoz, Yavaşoğlu ve Alpak Tunç, 2019; Tanık Önal, 2017; Boonmooh, Jumpakate ve Karplon, 2021). Bazı çalışmaların ise derste teknolojini kullanılmasına yönelik öğretim tasarımlarının oluşturulduğu belirlenmiştir (İnstefjord ve Munthe, 2016; Herro, Visser ve Qian, 2021). Bu çalışmalardan Hursen (2017) öğretmen adaylarının 
derste teknoloji kullanılmasına ilişkin eğilimlerini incelemiştir. Farklı disiplinlerde öğrenim gören 293 öğretmen adayının katıldığı çalışma sonucunda öğretmen adaylarının duyuşsal eğilim ortalama puanı 5'li Likert ölçeğinde 3.56 bulunurken, davranışsal eğilim ortalama puanı ise 3.37 olarak bulunmuştur. Hursen (2017) öğretmen adaylarının eğitimde teknoloji kullanımına yönelik eğilimlerinin belirlenmesinde nicel verilere ek olarak nitel verilerinde kullanılmasının önemli olduğunu belirtmiştir. Yine Şahin ve Arslan-Namlı (2019) öğretmen adaylarının eğitimde teknoloji kullanımına yönelik tutumlarını farklı disiplinlerden 300 öğretmen adayından veri toplayarak incelemiştir. Betimsel analiz sonuçlarına göre, öğretmen adaylarının teknoloji kullanmaya yönelik tutumları orta seviye olduğu $(\mathrm{M}=2.97)$ belirlenmiştir. En düşük ortalama puanlı bazı maddeler "Boş zamanlarımda eğitimde yeni teknolojilere ilişkin gelişmeleri takip etmekten hoşlanırım" ( $\mathrm{M}=2.67)$ maddesidir. Parker, Bianchi, ve Cheah (2008) ise 3145 öğrenci ve 485 akademisyenin katıldığı çalışmada akademisyenlerin teknoloji kullanma eğilimleri ve öğrencilerin öğrenme ve derse katılımlarını incelemiş̧tir. Frekans analizi sonucunda öğrenciler teknolojik araç-gereçlerin kullanılmasının derse ve sınıf içi tartışmalara katılımlarını olumlu etkilediğini ve derste daha iyi öğrendiklerini belirtmişlerdir. Alanyazında öğretmen adaylarının derste teknoloji kullanılmasına yönelik eğilimleri inceleyen çalışmalar ya öğrenci başarısı gibi farklı değişkenlerle ilişkilendirilmiş (Demirci Güler ve Irmak, 2018), ya da yalnızca nicel araştırma yöntemiyle düzeyler belirlenmeye (Kurtoğlu ve Seferoğlu, 2013) çalışılmıştır.

Uluslararası arenada Endüstri 4.0 kapsamında önemli gelişmeler yaşanmaktadır. Bu gelişmelerin içinde teknolojinin payı oldukça büyüktür. Bu sebepten teknoloji günümüzde olduğu gibi gelecekte de önemli bir ivme ile ilerlemeye devam edecektir. Bu bakımdan öğrencilerin, bilgi iletişim teknolojisi'nde (BİT) yaşanan gelişmelere ilişkin somut örnekleri bizzat görerek yakından takip etmesi ve bu ivmeye ayak uydurmasını sağlayacak olan eğitmenler en önemli etmendir (Durak ve Seferoğlu, 2017; Y1lmaz, 2016). Diğer taraftan Covid-19 pandemi sürecinin olumsuz etkilediği alanların başında eğitim-öğretim faaliyetleri gelmektedir. Ülkeler bu süreçte yüz yüze eğitimin açığını uzaktan eğitimle gidermeye çalışmıştır. Bu sürecin etkin olarak yürütülmesinde alt-yapı ve araç gerekçelere sahip olmanın önemli olduğu kadar (Instefjord ve Munthe, 2016) öğretmenlerin eğitimde teknoloji kullanma eğilimleri de önemlidir (Hursen, 2017). Bunun için öğretmen adaylarının eğitimde teknoloji kullanılmasına yönelik eğilimlerinin derinlemesine incelenmesi gerektiği düşünülmektedir. Ayrıca alanyazında yapılan çalışmalardaki örneklemler farklı disiplinlerdeki ögretmen adaylarından oluşmaktadır. Her ne kadar ortak alan kabul edilebilecek dersler bulunsa da her branşın öğretiminde, kendi doğası gereği farklı teknolojik araç-gereçlere ihtiyaç duyulmaktadır. Bu sebepten araştırma farklı braştan öğretmen adayları yerine tek branştaki öğretmen adaylarına odaklanmanın, daha derinlemesine incelemeye olanak sağlayacağı düşünülmektedir. Araştırma planlanırken de olgunun daha derinlemesine incelemeye olanak sağlayacak şekilde gerek nicel verilerin gerekse nitel verilerin güçlü yanlarına başvurularak desteklenmesi gerektiği önerilmektedir (Kurtoğlu ve Seferoğlu, 2013; Demirci Güler ve Irmak, 2018). Bu bağlamda mevcut araştırma, gelecekte fen öğretim sürecinin önemli etmenlerinden olan fen bilimleri öğretmen adaylarının derste teknoloji kullanımına yönelik eğilimlerini incelemeyi amaçlamıştır. $\mathrm{Bu}$ amaçla, çalışmada şu alt problemlere cevap aranmıştır:

Araştırma soruları:

1. Fen bilimleri öğretmen adaylarının derste teknoloji kullanmaya yönelik eğilimleri hangi düzeydedir?

2. Fen bilimleri öğretmen adaylarının derste teknoloji kullanmaya yönelik duygusal ve davranışsal eğilimleri arasında anlamlı far var mıdır?

3. Fen bilimleri öğretmen adaylarının derste teknoloji kullanmaya yönelik eğilimleri sınıf düzeyine göre anlamlı farkl1lık göstermekte midir?

4. Fen bilimleri öğretmen adaylarının derste teknoloji kullanmaya yönelik görüşleri nedir?

\section{Yöntem}

\section{Araştırmanın modeli}

Araştırma, karma yöntem desenlerinden yakınsayan paralel karma desen ile yürütülmüştür. Yakınsayan paralel desen, araştırma süresinin aynı aşamasında hem nicel hem de nitel verilerin toplandığı ve analiz edildiği ve ardından iki sonucun tek bir sonuç haline getirildiği araştırmalardır (Creswell, 2013). Bu desen türü, araştırmanın amacını ortaya koymada hem nitel hem de nicel verilere eşit düzeyde önem 
yüklediği için nicel yöntemlerin (geniş örneklem boyutu, eğilimler, genellemeler) ve nitel yöntemlerin (küçük örnek, ayrıntılar, derinlik) farklı güçlerini ve örtüşmeyen zayıflıklarını bir araya getirmektedir (Creswell ve Plano Clark, 2015). Paralel karma yöntemli araştırmalarda örneklem seçimi iki şekilde gerçekleşmektedir (Teddli ve Tashakkori, 2015). Bunlardan biri Paranis, Samar ve Fischer (2005)'in işitme engellileriyle yürüttüğü gibi tek bir örneklem grubundan kullanılmasıdır. Ancak mevcut araştırmada Laserre-Cortez (2006)'in nicel ve nitel araştırma sorularına ayrı yanıtlar bulmak için iki farklı örnekleme tekniğidir. Bu örnekleme tekniği araştırmanın farklı boyutlarını ortaya çıkarmak için amaçlı olarak çok sayıda durum veya birimden karşılaştırma çeşitliliği sunmaktadır (Teddli ve Tashakkori, 2015). Yakınsayan paralel desene ilişkin araştırma süreci Şekil-1'de diyagram şeklinde verilmiştir. Yakınsayan paralel desene ilişkin araştırma süreci Şekil-1'de diyagram şeklinde verilmiştir.

\begin{tabular}{|l|}
\hline $\begin{array}{l}\text { Veri toplama araçları: } \\
\text { Derste Teknoloji } \\
\text { Kullanımına Yönelik } \\
\text { Eğilim Ölçeği } \\
(\mathrm{n}=88)\end{array}$ \\
\begin{tabular}{|l}
\hline Verilerin analizi: \\
Derste Teknoloji \\
Kullanımına Yönelik \\
Eğilim Ölçeği \\
Bağımsız gruplar t- \\
testi
\end{tabular} \\
\hline
\end{tabular}

\section{E}
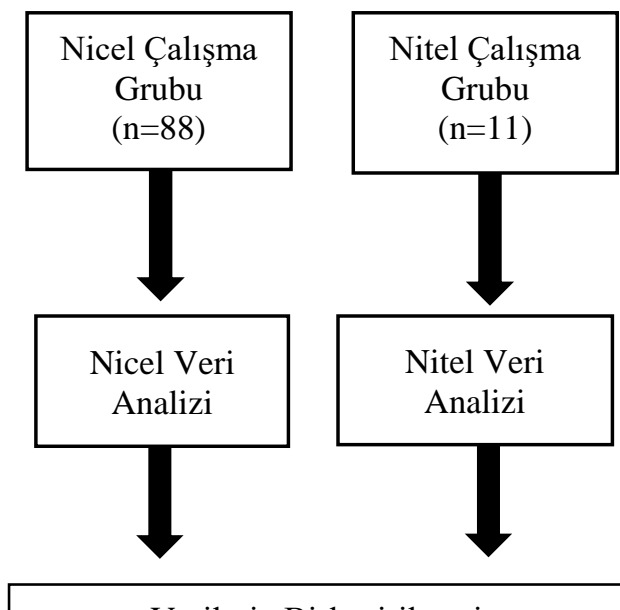

Verilerin Birleștirilmesi:

Derste Teknoloji Kullanımına Yönelik

Eğilim Ölçeği'nden elde edilen veriler ile

Yarı-yapılandırılmış görüşmeden elde

edilen verilerin birbirleriyle örtüşme ve

ayrışma durumu

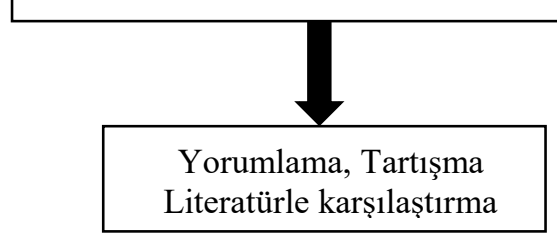

Şekil-1. Mevcut Araştırma Kapsamında Yürütülen Yakınsayan Paralel Karma Desen Diyagramı

\section{Çalışma Grubu}

Araştırma, nicel ve nitel olmak üzere iki farklı çalışma grubu ile yürütülmüştür. Bunlardan nicel çalışma grubunu bir devlet üniversitesine bağl1 fen bilgisi öğretmenliği programında öğrenim gören 1 ve 4 . sınıf toplam 88 öğrenci oluşturmaktadır. Böylece yükseköğretim sürecinin başında ve sonunda öğretmen adaylarının derste teknoloji kullanımına yönelik eğilimlerinin karşılaştıılması hedeflenmektedir. Nicel çalışma grubuna ilişkin detaylı bilgi Tablo 1'de sunulmuştur.

Tablo 1'e göre araştırmanın nicel grubu 67 kız ve 21 erkek öğrenciden oluştuğu görülmektedir. Yine aynı grupta yer alan öğrencilerin 28'i 1. sınıf, 60'1 4. sınıftan oluşmaktadır. Örneklem grubu arasındaki bu fark 1 ve 4. sınıf öğrencilerinin sınıf mevcudundan kaynaklanmaktadır. 
Tablo 1. Araşstırmaya Dâhil Edilen Örneklem Grubunun Cinsiyet ve Sınıf Düzeyi Açısından Dağılımı

\begin{tabular}{ccc}
\hline Cinsiyet & $\mathbf{N}$ & \% \\
\cline { 3 - 3 } Kiz & 67 & 76,2 \\
Erkek & 21 & 23,8 \\
& & $\%$ \\
\hline Sinıf Düzeyi & $\mathrm{N}$ & 31,8 \\
\hline 1. Sinıf & 28 & 68,2 \\
\hline 4. Sinif & 60 & $\%$ \\
\hline
\end{tabular}

Ayn1 konu hakkında farklı örneklemlerden farklı yöntemlerle elde edilen veri setlerinin birbiri ile karşılaştırılmasına olanak sağlamak (Creswell ve Plano Clark, 2015) amacıyla araştırmanın nitel çalışma grubunu ise nicel araştırmaya katılmayan 11 öğretmen adayı (1. sınıf 6 kişi; 4. sınıf 5 kişi) oluşturmaktadır.

\section{Veri Toplama Araçları}

Araştırmada hem nitel veriler hem de nicel verilerin toplanma süreci, 2019-2020 eğitim-öğretim yılı güz yarıyılında gerçekleşmiştir. Öğretmen adaylarının fen bilimleri dersinde teknoloji kullanmaya yönelik eğilimleri nicel araştırma yöntemiyle ortaya koymak amacıyla Günüç ve Kuzu (2014) tarafindan geliştirilen Derste Teknoloji Kullanımına Yönelik Eğilim Ölçeği kullanılmıştır. Bu ölçek 5'li likert tipinde olup öğrencilerin derste teknoloji kullanımlarını duyuşsal ve davranışsal olmak üzere 2 boyutta ölçmektedir. Duyuşsal boyut 11 madde ile ölçülürken davranışsal boyut 5 madde ile temsil edilmektedir. Ölçeğin iç tutarlılık katsayısı ise ,93 olarak hesaplanmıştır. Mevcut araştırmada ise iç tutarlılık katsayısı, ölçeğin; geneli için 0,95, duyuşsal boyutu için 0,86 ve davranışsal boyutu için 0,89 olarak hesaplanmıştır.

Diğer taraftan, öğretmen adaylarının derste teknoloji kullanmaya yönelik gerek deneyimleri gerekse düşüncelerini daha derinlemesine ele alabilmek amaciyla nitel görüşme gerçekleştirilmiştir. Görüşme sorularıyla, öğretmen adaylarının derste teknoloji kullanımına ilişkin hangi deneyime sahip olduğu, hangi teknolojik deneyime sahip olmak istediği, eğitimde teknolojiden ne beklediği ve teknolojinin

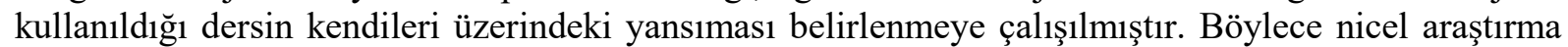
bulgularının nedensel olarak açıklanması da beklenmektedir. $\mathrm{Bu}$ amaçla 8 adet görüşme sorusu geliştirilmiştir. Bu sorular, biri fen eğitimi diğeri bilgisayar ve öğretim teknolojileri eğitimi alan uzmanı iki kişi tarafından değerlendirilmiştir. İki alan uzmanının birbiriyle tutarlı değerlendirme sonucuna göre aynı amaca hizmet eden iki sorudan birinin çıkarılmasına karar verilmiştir. Böylece toplam 7 adet görüşme sorusu, pilot uygulama için hazır hale gelmiştir. Pilot uygulamada biri birinci sınıf, diğeri dördüncü sınıf iki kişiye bu 7 soru yöneltilmiş ve alınan cevapların ne derece araştırmanın amacına hizmet ettiği incelenmiştir. Ayrıca öğrencilere bu soruların kendisine ne anlatmak istediği, anlaşılmayan bir noktanın olup olmadığ 1 sorulmuştur. Öğrencilerden gelen geri bildirimler neticesinde ise iki sorunun daha iyi anlaşılmasını sağlamak için son düzeltmeler yapılmıştır.

Tablo 2. Görüşme Sirasında Öğrencilere Yöneltilen Sorular

1- Sizce teknoloji nedir?

2- Günlük hayatta teknolojiden nasıl faydalanıyorsunuz?

3- Öğrencilik hayatınız boyunca teknolojiden nasıl faydalanıyorsunuz?

4- Sizce teknoloji sınıflarda nasıl kullanılması gerekir?

5- Sizce öğretim elemanları derslerde teknolojiyi yeterince kullanıyorlar mı? Öğretim elemanları bir dersin öğretimini oluştururken nelere dikkat etmelidir?

6- Derslikler nasıl bir teknolojik altyapıya sahip olmalıdır?

7- Ögretim elemanın teknoloji becerisi, sizin derslerde teknoloji kullanımınızı etkiler mi? Neden?

\section{Verilerin Analizi}

Araştırmanın amacı doğrultusunda toplanan nicel veriler SPSS 24 paket programları kullanılarak yapılmıştır. Analiz sonuçlarının yorumlanmasında hata payının üst sınırı 0.05 olarak kabul edilmiştir. Nicel verilerin normal dağılım gösterip göstermediği çarpıklık ve basıklık katsayısı ve KolmogorovSmirnov testi ile belirlenmiştir. Buna göre elde edilen verilerin çarpıklık katsayısı, $-0,519( \pm 0,201)$; 
basıklık katsayısı ise $0,091( \pm 0,399)$ olarak hesaplanmıştır. Bu katsayıların +1 ile -1 arasında olması normallik varsayımını karşılamaktadır (Çokluk, Şekercioğlu ve Büyüköztürk, 2012). Diğer taraftan Kolmogorov-Smirnov testi sonucu .20 olarak hesaplanmıştır. Buna göre çarpıklık-basıklık katsayıların +1 ile -1 arasında olması (Çokluk, Şekercioğlu ve Büyüköztürk, 2012) ve Kolmogorov-Smirnov değerinin 0.05 değerinden büyük olması (Kalaycı, 2006), araştırmadan elde edilen verilerin normallik varsayımını karşıladığı söylenebilir. Öğretmen adaylarının derste teknoloji kullanımına yönelik eğilim düzeyleri betimsel analiz ile; sınıf düzeyi değişkenine göre nasıl değişim gösterdiği bağımsız gruplar ttesti ile; ölçeği oluşturan duygusal eğilim ile davranışsal eğilim boyutları arasındaki fark ise bağımlı gruplar t-testi ile çözümlenmiştir.

Görüşme sırasında öğrencilerle yapılan konuşma verilerinin kayba uğramadan toplanabilmesi için ses kaydı yapılmıştır. Ses kaydının yapılması için her bir öğrencinin rızası alınmıştır. Görüşmeden elde edilen ses kayıtları, araştırmacıdan bağımsız bir kişi tarafından yazılı metne dökülmüştür. Bu yazılı metin üzerinde içerik analizi yapılmıştır. Yazıya aktarılan ifadeler, öğrencilerin verdikleri cevaplara göre temalar oluşturulmuştur. Öğrencilerin ifadelerinin içerik analizi sonucunda alt-temalar, bazı sorular için tümevarımsal olarak; bazıları için ise alan yazın taraması (Herdem, Aygün ve Çinici, 2012; Başer, Mutlu, Şendurur ve Şendurur, 2012) ile belirlenmiştir. İçerik analizinin güvenirliği kodlayıcılar arası tutarlılık incelenerek belirlenmiştir. Kodlayıcılar arası tutarlılık, Miles ve Huberman'ın (1994) belirtmiş olduğu güvenirlik hesaplama formülü ile kodlayıcılar arasındaki görüş birliği oranına göre belirlenmiştir.

\section{Bulgular}

Araştırma sürecinde hem nicel bulgular hem de nitel bulgular elde edilmiştir. Bu sebepten elde edilen bulgular ayrı başlıklar altında toplanmıştır.

\section{Birinci Araştırma Sorusuna Yönelik Bulgular}

Fen bilimleri öğretmen adaylarının derste teknoloji kullanımına yönelik eğilimleri gerek ölçeğin geneli gerekse boyutlarına göre hangi düzeyde olduğu betimsel istatistik ile çözümlenmiştir. Buna ilişkin olarak elde edilen bulgular Tablo 3'de verilmiştir.

Tablo 3. Fen Bilimleri Öğretmen Adaylarının Derste Teknoloji Kullanımına Yönelik Eğilimlerin Boyutlara Göre Betimsel İstatistik Sonuçları

\begin{tabular}{lccc}
\hline \multicolumn{1}{c}{ Ölçeğin boyutları } & $\mathbf{N}$ & $\overline{\mathbf{x}}$ & $\mathbf{S}$ \\
\hline Duyuşsal eğilim & & 4,04 & 0,67 \\
Davranışsal eğilim & 88 & 3,81 & 0,85 \\
Ölçeğin geneli & 88 & 3,97 & 0,69 \\
\hline
\end{tabular}

Tablo 3'e göre öğretmen adaylarının teknolojiye yönelik eğilimleri ortalaması 5 üzerinden 3,97 olarak hesaplanmıştır. Diğer taraftan ölçeği oluşturan davranışsal eğilim boyutuna ilişkin ortalama 3,81; duyuşsal eğilim boyutuna ilişkin ortalama ise 4,04 olarak bulunmuştur. Buradan öğretmen adaylarının derste teknoloji kullanımına yönelik eğilimlerinin iyi düzeyde olduğu söylenebilir. Ayrıca duyuşsal eğilime ilişkin ortalamanın davranışsal eğilime göre daha yüksek olduğu görülmektedir.

Fen bilimleri öğretmen adaylarının derste teknoloji kullanımına yönelik eğilimleri ortaya koyan maddelere ilişkin betimsel analiz sonuçları Tablo 4'te sunulmuştur. 
Tablo 4. Fen Bilimleri Öğretmen Adaylarının Derste Teknoloji Kullanımına Yönelik Eğilimlerine İlişkin Betimsel İstatistik Sonuçları

\begin{tabular}{|c|c|c|c|}
\hline Boyutlar & Maddeler & Ort. & $\begin{array}{c}\text { Standart } \\
\text { sapma }\end{array}$ \\
\hline \multirow{11}{*}{ Duyuşsal } & 1- Derslerde teknolojinin daha çok kullanılmasını isterim & 4,18 & 0,91 \\
\hline & 2- Teknolojinin kullanıldığı dersler daha eğlencelidir & 4,07 & 0,94 \\
\hline & $\begin{array}{l}\text { 3- Ders sorumluluklarında/ödevlerinde teknolojiyi kullanmak } \\
\text { işimi kolaylaştırır }\end{array}$ & 4,29 & 0,80 \\
\hline & 4- Teknolojinin kullanıldığı dersleri daha çok önemserim & 3,69 & 1,09 \\
\hline & $\begin{array}{l}\text { 5- Öğretim elemanları ile İnternet üzerinden de iletişime geçmek } \\
\text { hoşuma gider }\end{array}$ & 3,86 & 1,05 \\
\hline & 6- Teknolojinin kullanıldığı derslerde daha iyi öğrenirim & 3,87 & 1,00 \\
\hline & 7- Derslerde yeni/farklı teknolojilerin kullanılmasını isterim & 4,21 & 0,83 \\
\hline & $\begin{array}{l}\text { 8- Sınıf arkadaşlarımla İnternet üzerinden derslere ilişkin } \\
\text { paylaşımda bulunmak hoşuma gider }\end{array}$ & 4,19 & 0,87 \\
\hline & 9- Teknoloji ile öğrenmek daha hoşuma gider & 4,12 & 0,88 \\
\hline & 10- Teknolojinin her derste kullanılmasını isterim & 3,94 & 1,00 \\
\hline & 11- Derslerde teknolojinin kullanılması ilgimi artırır & 4 & 0,87 \\
\hline \multirow{5}{*}{ Davranışsal } & 12- Teknolojinin kullanıldığı derslere daha çok devam ederim & 3,79 & 1,01 \\
\hline & 13- Teknolojinin kullanıldığı derslerde daha aktif olurum & 3,85 & 0,97 \\
\hline & 14- Teknolojinin kullanıldığı derslere daha istekli giderim & 3,84 & 1,03 \\
\hline & 15- Teknolojinin kullanıldığı dersleri daha iyi dinlerim/takip ederim & 3,88 & 0,97 \\
\hline & 16- Teknolojinin kullanıldığı derslere daha hazırlıklı giderim & 3,69 & 0,95 \\
\hline Ortalama & & 3,97 & $\mathbf{0 , 5 0}$ \\
\hline
\end{tabular}

Tablo 4 incelendiğinde duyuşsal boyuta ilişkin maddelerin ortalaması genellikle 4 değerinin üzerinde seyrederken, davranışsal boyuta ilişkin maddelerin ortalaması 4'ün altındadır. Duyuşsal boyuta ilişkin olarak teknolojinin kullanıldığı dersleri daha çok önemseme $(\overline{\mathrm{x}}: 3,69)$ ve öğretim elemanlart ile internet üzerinden de iletişime geçme ( $\mathrm{x}: 3,86)$ en düşük; ders sorumluluklarında veya ödevlerinde teknolojiyi kullanmanin işi kolaylaştırma $(\overline{\mathrm{x}}: 4,29)$ ve derslerde yeni/farkl teknolojiler kullanma $(\overline{\mathrm{x}}: 4,21)$ maddeleri ise diğerlerine göre daha yüksek ortalamaya sahip olduğu görülmektedir. Davranışsal boyuta ilişkin olarak teknolojinin kullanıldiğı derslere daha hazırlıkl gitme diğerlerine göre en düşük $(\overline{\mathrm{x}}: 3,69)$, teknolojinin kullanıldı $\breve{l}$ dersleri daha iyi dinlerim/takip etme ise diğerlerine göre en yüksek $(\overline{\mathrm{x}}: 3,88)$ ortalamaya sahip olduğu görülmektedir. $\mathrm{Bu}$ yüzden her ne kadar derslerde yeni/farklı teknolojilerin kullanılması öğretmen adayları tarafından talep edilse de ilgili ders için yeni teknolojilerin keşfedilmesinde yapılan ön hazırlıklar, aynı düzeyde yapılmadığı söylenebilir.

\section{İkinci Araştırma Sorusuna Yönelik Bulgular}

Fen bilimleri öğretmen adaylarının derste teknoloji kullanmaya yönelik duyuşsal ve davranışsal eğilimleri arasında anlamlı fark olup olmadığı bağımlı gruplar t-testi ile çözümlenmiştir. Buna ilişkin olarak elde edilen bulgular Tablo 5'de verilmiştir.

Tablo 5'e göre fen bilimleri öğretmen adaylarının derste teknoloji kullanmaya yönelik duyuşsal ve davranışsal eğilimleri arasında duyuşsal eğilim lehine anlamlı fark ortaya çıkmıştır $[t(87)=-3,96$, $\mathrm{p}<0,05]$. Bu bulgular ışığında fen bilimleri öğretmen adaylarının derste teknoloji kullanımına yönelik duyuşsal eğilimin, davranışsal eğilime göre daha yüksektir. Diğer bir ifade ile fen bilimleri öğretmen adayları ögrenim gördüğü derste teknolojiyi kullanmak istedikleri, ancak bunu tam olarak davranış haline getiremedikleri söylenebilir. 
Tablo 5. Fen Bilimleri Öğretmen Adaylarının Derste Teknoloji Kullanımına Yönelik Eğilimlerin Boyutlara Göre Bağımlı Gruplar T-Testi Sonuçları

\begin{tabular}{lcccccc}
\hline \multicolumn{1}{c}{ Ölçeğin boyutları } & $\mathbf{N}$ & $\overline{\mathbf{x}}$ & $\mathbf{S}$ & $\mathbf{s d}$ & $\mathbf{t}$ & $\mathbf{p}$ \\
\hline Duyuşsal eğilim & 88 & 4,04 & 0,67 & $-3,96$ & 87 & 0,00 \\
Davranışsal eğilim & 88 & 3,81 & 0,85 & & & \\
Ölçeğin geneli & 88 & 3,97 & 0,69 & & & \\
\hline
\end{tabular}

\section{Üçüncü Araştırma Sorusuna Yönelik Bulgular}

Fen bilimleri öğretmen adaylarının derste teknoloji kullanmaya yönelik eğilimleri sınıf düzeyine göre anlamlı fark olup olmadığı bağımlı gruplar t-testi ile analiz edilmiştir. Analiz sonuçları Tablo 6'da verilmiştir.

Tablo 6. Fen Bilimleri Öğretmen Adaylarının Derste Teknoloji Kullanmaya Yönelik Eğilimlerin Sinıf Düzeyine Göre t-testi Sonuçları

\begin{tabular}{lccccccc}
\hline Ölçeğin boyutları & Sınıf Düzeyi & $\mathbf{N}$ & $\overline{\mathbf{x}}$ & $\mathbf{S}$ & $\mathbf{s d}$ & $\mathbf{t}$ & $\mathbf{p}$ \\
\hline \multirow{2}{*}{ Duyuşsal eğilim } & 1. sınıf & 28 & 3,77 &, 67 & 86 & $-3,399$ &, 00 \\
& 4. sınıf & 60 & 4,23 &, 53 & & & \\
\hline \multirow{2}{*}{ Davranışsal eğilim } & 1. sınıf & 28 & 3,65 &, 76 & 86 & $-1,839$ &, 07 \\
& 4. sinıf & 60 & 3,98 &, 77 & & & \\
\hline \multirow{2}{*}{ Ölçeğin geneli } & 1. sinıf & 28 & 3,74 &, 66 & 86 & $-3,010$ &, 01 \\
& 4. sınıf & 60 & 4,15 &, 56 & & & \\
\hline
\end{tabular}

Tablo 6'ya göre fen bilimleri öğretmen adaylarının derste teknoloji kullanmaya yönelik eğilimi ölçeğin geneli açısından incelendiğinde 4. sınıf lehine anlamlı farklılık olduğu ortaya çıkmıştır $[\mathrm{t}(86)=-3,010$, $\mathrm{p}<, 05]$. Ayrıca sınıf düzeylerine göre duyuşsal eğilim, 4. sınıf lehine anlamlı farklılık gösterirken [t(86) $=-3,399, \mathrm{p}<, 05]$; davranışsal eğilim ise anlamlı farklılık göstermemektedir [t(86) =-1,839, $\mathrm{p}>, 05]$. Bu bulgulara göre 4. sınıf düzeyinde öğrenim gören fen bilimleri öğretmen adaylarının derste teknoloji kullanmaya yönelik eğilimi $(\bar{x}=4,15), 1$. sinıflara göre $(\bar{x}=3,74)$ daha yüksektir. Benzer şekilde 4 . sınıf düzeyinde öğrenim gören fen bilimleri öğretmen adaylarının derste teknoloji kullanmaya yönelik duyuşsal eğilimi $(\overline{\mathrm{x}}=4,23), 1$. sınıflara göre $(\overline{\mathrm{x}}=3,77)$ daha yüksektir.

\section{Dördüncü Araştırma Sorusuna Yönelik Bulgular}

Araştırmanın nitel aşamasında nicel veri toplama sürecine katılmamış 11 öğretmen adayı ile yarıyapılandırılmış görüşme gerçekleştirilmiştir. Görüşmenin amacı, nicel örneklem grubu ile aynı özellikleri taşıyan ancak farklı katılımcıların derste teknoloji kullanımına yönelik eğilimlerini nitel araştırma yöntemiyle belirlemektir. Böylece nitel veriler ile nicel verilerin ne derece örtüştüğ̈̈nü/ayrıştığını ya da nitel veriler ile nicel verilerin birbirini hangi hususlarda desteklediğini tespit etmektir. Görüşmeden elde edilen cevapların frekansı, görüşmeye katılan toplam kişi sayısını yansıtmadığından dolayı yüzde değeri verilmemiştir. Görüşmeden elde edilen bulgulara ilişkin içerik analizi Tablo 7'de verilmiştir. 
Tablo 7. Fen Bilimleri Öğretmen Adaylarının Derste Teknoloji Kullanımına Yönelik Düşüncelerinin İçerik Analizi (Soru 1/2/3)

\begin{tabular}{|c|c|c|c|c|}
\hline Soru & Temalar & Alt temalar & f & Örnek öğrenci ifadeleri \\
\hline \multirow[t]{2}{*}{$\begin{array}{c}\text { Teknoloji } \\
\text { nedir? }\end{array}$} & \multirow[t]{2}{*}{$\begin{array}{l}\text { Yarar } \\
\text { (Fayda) }\end{array}$} & Kolaylık & 9 & $\begin{array}{l}\text { Ö}_{5} \text { "Teknoloji 1. sinıf devletler için zengin olmaya } \\
\text { yarar(ticari), 2. sınıf devletler için hayatı kolaylaştıran } \\
\text { yapıdır" } \\
\ddot{\mathbf{O}}_{1} \text { “derslerde öğrenmeyi kolaylaştırma" } \\
\text { Ö. }_{\mathbf{8}} \text { "İcat edilen her şey, problemlere karşı bulunan her } \\
\text { çözüm..." }\end{array}$ \\
\hline & & Ürün & 2 & $\ddot{\mathbf{O}}_{2}$ "Bilimin uğraşıları sonucu ortaya çıkan araç-gereçler" \\
\hline \multirow{4}{*}{$\begin{array}{c}\text { Günlük } \\
\text { hayatta } \\
\text { teknolojiden } \\
\text { nasil } \\
\text { faydalaniyorsunuz? }\end{array}$} & \multirow{2}{*}{ Eğlence aracı } & Sosyal medya & 11 & Tüm katılımcılar “...sosyal medyada eğlence amaçlı...” \\
\hline & & Gündem takibi & 3 & $\begin{array}{l}\ddot{O}_{4} \text { “... gündemi takip etmek ve bilgiye ulaşmak için } \\
\text { kullanıyorum ..." }\end{array}$ \\
\hline & \multirow{2}{*}{$\begin{array}{l}\text { Günlük } \\
\text { gereksinimler }\end{array}$} & İletişim & 4 & Ö. “Telefonla iletişim sağlama...” \\
\hline & & $\begin{array}{l}\text { Günlük temel } \\
\text { ihtiyaçlar }\end{array}$ & 2 & $\begin{array}{l}\text { Ö}_{11} \text { "Çamaşır makinesi gibi günlük temel ihtiyaçlar } \\
\text { için..." }\end{array}$ \\
\hline \multirow{3}{*}{$\begin{array}{c}\text { Öğrencilik } \\
\text { hayatınız } \\
\text { boyunca } \\
\text { teknolojiden nasıl } \\
\text { faydalanıyorsunuz? }\end{array}$} & \multirow{3}{*}{$\begin{array}{l}\text { Eğitim } \\
\text { Öğretim } \\
\text { süreci }\end{array}$} & $\begin{array}{l}\text { Öğretimde yeni } \\
\text { teknolojiler }\end{array}$ & 8 & $\begin{array}{l}\ddot{O}_{10} \text { “Artırılmış gerçeklik...” } \\
\ddot{\mathbf{O}}_{\mathbf{8}} \text { “Aktllı tahtalar, mikroskop...” }\end{array}$ \\
\hline & & $\begin{array}{l}\text { Konuların } \\
\text { öğrenimi }\end{array}$ & 5 & 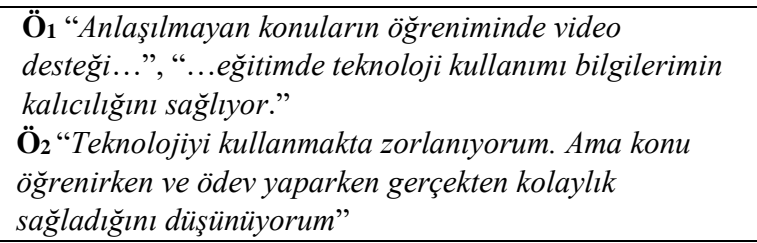 \\
\hline & & Ödev hazırlama & 4 & $\ddot{O}_{4}$ “Ödevleri araştırma" \\
\hline \multirow[t]{3}{*}{$\begin{array}{l}\text { Sizce teknoloji } \\
\text { siniflarda nasıl } \\
\text { kullanılması } \\
\text { gerekir? }\end{array}$} & \multirow[t]{3}{*}{$\begin{array}{c}\text { Öğretim } \\
\text { teknolojileri }\end{array}$} & $\begin{array}{l}\text { Görsel ve işitsel } \\
\text { duyulara hitap }\end{array}$ & 7 & 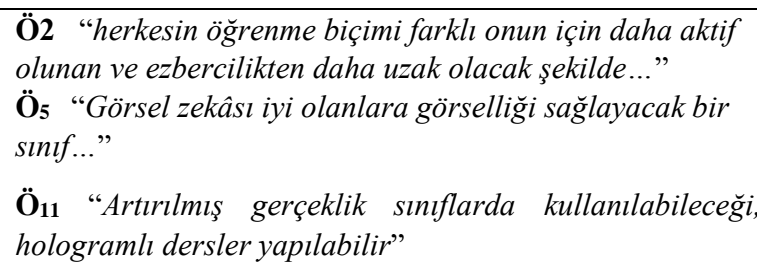 \\
\hline & & Ak1lli tahta & 5 & $\begin{array}{l}\text { Ö}_{4} \text { "Öğretmenin akıllı tahtadan ders işlemesi ve tabletten } \\
\text { takip edilmesi" }\end{array}$ \\
\hline & & Uzaktan eğitim & 1 & $\ddot{\mathrm{O}}_{3}$ "....bazı dersler uzaktan eğitim ile verilebilir" \\
\hline
\end{tabular}

Görüşmeye katılan öğretmen adaylarının teknoloji algısı yarar (fayda) teması altında toplanmıştır. Buna göre katılımcıların çoğunluğu (f=9) teknolojinin hayatı kolaylaştırma yönü (öğrenmeyi kolaylaştırma, hayatı kolaylaştırma ve problemlere çözümler bulma) üzerinde dururken, 2 kişi teknolojiyi bilimin uğraşıları sonucunda ortaya çıkan ürün açısından ele almıştır. Diğer bir ifade ile teknoloji, bilimin uğraşıları sonucu ortaya çıkan ürün ve bu ürünlerin kullanımıyla insanların karşılaştığı problemlerin çözümünde kolaylaştırıcı bir unsur olarak görülmektedir.

Görüşmede ikinci soru olarak günlük hayatta teknolojiden nasıl faydalanıldığı sorulmuştur. İçerik analizi sonuçlarına göre cevaplar eğlence aracı ve günlük gereksinimler teması altında toplanmıştır. Ĕglence aracı teması bağlamında öğretmen adayları teknolojiyi; en fazla sosyal medya amacıyla (f=11), bunun dışında dünya gündeminin olağan seyrini takip etmek amacıyla $(\mathrm{f}=3)$ kullanmaktadır. Günlük gereksinimler bağlamında teknoloji iletişim sağlama $(\mathrm{f}=4)$ ve günlük temel ihtiyaçların karşılanması $(\mathrm{f}=2)$ için yararlanıldığ faydalanıldı̆̆ 1 sorusuna verilen cevaplar, eğitim-öğretim süreci temas1 altında toplanmıştır. Ĕ̈itimögretim süreci teması ögretimde yeni teknolojiler, konuların ögrenimi ve ödev hazırlama alt temalarından oluşmaktadır. Öğretimde yeni teknolojiler alt teması, öğretmen adaylarının eğitimögretim sürecinde en fazla kullandığı veya karşılaştığı teknolojilerin (akıllı tahta, projeksiyon, mobil uygulamalar, artırılmış gerçeklik, mikroskop) neler olduğu; konuların öğrenimi teması, Kamu Personeli 
Seçme Sınavına hazırlanmak için ders içerikli videolar takip edilmesi ( $\mathrm{f}=5$ ); ödev hazırlama alt teması ise üniversite dersleri kapsamında sunum veya ödevlerin yapılması $(\mathrm{f}=4)$ anlamına gelmektedir. Öğretim ortamlarında kullanımı sıradanlaşan (powerpoint vb.) mevcut teknolojilerin dışında, yeni ve farklı ögretim teknolojisinin araştırılıp sınıf ortamına getirilip getirilmediği sorusu, konuyu derinleştirmek amacıyla sorulmuştur. Ancak fen bilimleri öğretmen adayları, gerek sorumlu olduğu ödevleri destekleyici teknolojileri gerekse özel öğretim yöntemleri veya öğretmenlik uygulamaları gibi derslere hazırlık yapmak amacıyla farklı teknolojileri araştırılma ya da sınıf ortamında paylaşılma gibi bir uğraşı içinde olmadıkları tespit edilmiştir. Bu durumun sebebi olarak öğretmen adayları kendilerine verilen görevleri, asgari şekilde yerine getirme ve bu kişinin farklılık yaratacak bir uğraşı içerisine girmek istememesinden kaynaklandığı düşünülmektedir.

Teknolojinin öğrenme ortamlarında nasıl kullanılması gerektiği sorusu öğretmen adaylarına dördüncü soru olarak yöneltilmiştir. Elde edilen cevaplar öğretim teknolojileri teması altında toplanmıştır. $\mathrm{Bu}$ tema, görsel/işitsel duyulara hitap, akıllı tahta, uzaktan eğitim alt temaları altında toplanmıştır. Görsel/işitsel duyulara hitap alt teması bağlamında artırılmış ve sanal gerçeklik, robotik ve kodlama, hologram ve mobil uygulamaların kullanımında görsel ve işitsel duyulara hitap eden bir öğretimin gerçekleşmesi en fazla ifade edilen görüş ( $f=7)$ arasındadır. Bu cevabı veren öğrencilerin çoğu $(f=5) 4$. sınıf düzeyinde öğrenim görmeleri, yükseköğretim sürecinin etkisini ön plana çıkartmış olabilir. Zira 4. sınıf öğrencilerinin fen öğretimi laboratuvar uygulamaları dersinde hologram ve sanal gerçeklik uygulamalarından; öğretmenlik staj uygulamasında arttırılmış gerçeklik ve çeşitli mobil cihazlarından; kişisel gelişim adına üniversite bünyesinde robotik ve kodlama eğitimi almış olmasından kaynaklandığı düşünülmektedir. Akıllı tahta alt teması bağlamında özellikle birinci sınıf öğretmen adayları ders sırasında bilgisayarlardan ve bilgisayar özelliği gösteren akıllı tahtalardan daha fazla yararlanılması gerektiğini önermiştir. Bu durum birinci sınıf öğrencilerin ortaöğretim FATİH Projesi kapsamında akı1lı tahta ile öğrenim süreci geçirmesinden kaynaklandığ 1 düşünülmektedir. Buna karşın dördüncü sınıf ögretmen adayları ise eğitimde teknolojinin sadece PowerPoint'e dayalı bir sunum veya akıllı tahta aracılığıyla görsellerin gösterimi ile sınırlı kalmaması gerektiği, bununla beraber her öğrencinin bireysel farklılıkları gözetilecek şekilde daha farklı teknolojik ürünlerin (3 boyutlu modeller, Artırılmış gerçeklik, Ters-yüz modeller) sınıf ortamına getirilmesi gerektiğini belirtmişlerdir. Ancak günümüz sınıf ortamlarının çoğunda kullanılan akıllı tahtaların da kendilerine mutlaka öğretilmesi gerektiği $(\mathrm{f}=2)$ ifade edilmiştir. Buradan 4. sınıf öğrencileri, öğretimde teknoloji çeşitliliğine (3B görseller, ters yüz model, artırılmış gerçeklik, akıllı tahta vb.) daha fazla yer verilmesini talep ederken birinci sınıf öğrencileri bilgisayar ve akıllı tahta ile sınırlı kaldığı görülmektedir. Diğer taraftan bir öğrencinin ise pandemi öncesi olmasına rağmen, öğrenme sürecinde uzaktan eğitimden faydalanma düşüncesi araştırmacılar tarafindan oldukça şaşırtıcı karşılanmıştır. Bu durum öğretim ilke ve yöntemleri dersinde uzaktan eğitim konusuna yer verilmesinden kaynaklandığı düşünülmektedir.

Görüşmenin beşinci sorusu olarak öğretmen adaylarına derslerde teknolojinin yeterince kullanılıp kullanılmadığı ve öğretim üyelerinin bir dersin öğretimini tasarlarken nelere dikkat etmesi gerektiği sorulmuştur. Böylece öğretmen adayına göre bir dersin öğretim tasarımında teknolojiyi dikkate alıp almadığının belirlenmesi hedeflenmiştir. Görüşmeden elde edilen bulgulara ilişkin içerik analizi Tablo 8 'de verilmiştir.

Elde edilen bulgulara göre birinci sınıf öğretmen adayları, öğretim görevlileri/üyelerinin bazıları derste teknolojiden yararlanırken bazılarının ise yararlanmadığını ifade etmişlerdir. Teknolojinin kullanıldığı dersler ise genellikle PowerPoint sunumları ile sınırlı kaldığı, sunumların açılmaması ya da açılma sürecinde yaşanan bir takım problemlerin derse olan ilgi ve motivasyonu olumsuz yönde etkilediği belirtilmiştir. Böylece gerek birinci sınıf gerekse dördüncü sınıf öğretmen adaylarına göre öğretim görevlileri/üyelerinin derste teknolojiden yeterince faydalanmadığı söylenebilir. 
Tablo 8. Fen Bilimleri Öğretmen Adaylarının Derste Teknoloji Kullanımına Yönelik Düşüncelerinin İcerik Analizi (Soru 5/6/7)

\begin{tabular}{|c|c|c|c|c|}
\hline Soru & Temalar & $\begin{array}{l}\text { Alt } \\
\text { temalar }\end{array}$ & $\mathbf{f}$ & Örnek öğrenci ifadeleri \\
\hline \multirow[b]{2}{*}{$\begin{array}{l}\text { Sizce öğretim } \\
\text { elemanları derslerde } \\
\text { yeterince teknolojiyi } \\
\text { kullanıyorlar mı? }\end{array}$} & \multirow[b]{2}{*}{ Yanitlar } & Evet & 1 & $\ddot{O}_{1}$ "Evet, projeksiyon kullanılıyor" \\
\hline & & $\begin{array}{l}\text { Yeterince } \\
\text { kullanılmiyor }\end{array}$ & 10 & $\begin{array}{l}\ddot{O ̈}_{2} \text { "Slaytlar kullanılıyor ancak bunu kullanamayanlar } \\
\ddot{O}_{3} \text { "Bazıları kullanıyor ama çoğu kullanmıyor } \\
\ddot{O}_{4} \text { "Yeterince kullanılmıyor ve kullanıldığında da sadece } \\
\text { slayt } \\
\ddot{O}_{7} \text { "Yeterli değil, sadece projeksiyon var" }\end{array}$ \\
\hline \multirow{3}{*}{$\begin{array}{l}\text { Öğretim elemanları } \\
\text { bir dersin içeriğini } \\
\text { oluştururken nelere } \\
\text { dikkat etmelidir? }\end{array}$} & \multirow{2}{*}{$\begin{array}{l}\text { Yap1lmas1 } \\
\text { gerekenler }\end{array}$} & Görsellik & 8 & 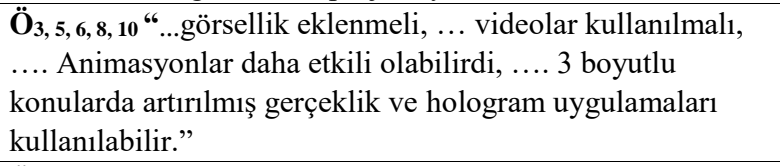 \\
\hline & & $\begin{array}{l}\text { Öğretim } \\
\text { teknolojilerinin } \\
\text { tanıtımı }\end{array}$ & 3 & $\begin{array}{l}\ddot{\mathbf{O}}_{\mathbf{1}, \mathbf{4}, \mathbf{1 0}} \text { “.. Ak1llı tahtadan ders işlenmesi yararlı olabilir, } \\
\text {..Derslerde farklı farklı teknolojik ürünlerden } \\
\text { faydalanılabilir." }\end{array}$ \\
\hline & $\begin{array}{l}\text { Yap1lmamas1 } \\
\text { gerekenler }\end{array}$ & $\begin{array}{l}\text { Salt sunumun } \\
\text { terkedilmesi }\end{array}$ & 5 & $\begin{array}{l}\ddot{O}_{2,7,9,11} \text { “....Böyle olunca teknolojiyi kullanmış olmayız. } \\
\text { Sunumlardan daha fazlasını yapmalı, } \\
\text { Ö}_{10} \text { “..dersler projeksiyona hapis olunmuş bir şekilde } \\
\text { işleniyor. Sonra bizlere derslerde çeşitli teknolojik cihazların } \\
\text { kullanılması gerektiği söyleniyor...” }\end{array}$ \\
\hline \multirow{4}{*}{$\begin{array}{l}\text { Derslikler nasıl bir } \\
\text { teknolojik altyapıya } \\
\text { sahip olmalıdır? }\end{array}$} & \multirow{4}{*}{$\begin{array}{l}\text { Teknolojik } \\
\quad \text { sinıf }\end{array}$} & $\begin{array}{l}\text { Mobil telefon } \\
\text { /Tabletler }\end{array}$ & 5 & $\begin{array}{l}\ddot{O}_{3} \text { "... akıllı tahta ile uyumlu tabletler bulunabilir" } \\
\ddot{O ̈}_{5} \text { "Her sırada bir öğrenci ve öğrencilerde tablet ve } \\
\text { bilgisayar...." }\end{array}$ \\
\hline & & Akıllı Tahta & 4 & $\ddot{\mathbf{O}}_{2,3,4,6}$ “...akıllı tahta, tabletlerin olduğu bir sınıf olabilir” \\
\hline & & Bilgisayar & 4 & $\begin{array}{l}\ddot{O}_{4, \mathbf{5}, \mathbf{8}, \mathbf{1 0}} \text { "..her sinıfta internet erişimi olan } 3-4 \text { tane } \\
\text { bilgisayar", "... kişisisel bilgisayarlar daha fazla olabilir." }\end{array}$ \\
\hline & & $\begin{array}{l}\text { Çeşitli } \\
\text { teknolojik } \\
\text { ürünler }\end{array}$ & 3 & $\begin{array}{l}\ddot{O}_{1,7,10,11} \text { "Artırılmış gerçeklik, ...kodlama, ...elektron } \\
\text { mikroskobu, .... } 3 \text { boyutlu gösterim sağlayan teknolojiler " }\end{array}$ \\
\hline \multirow[b]{2}{*}{$\begin{array}{l}\text { Öğretim elemanın } \\
\text { teknoloji becerisi, } \\
\text { derslerde teknoloji } \\
\text { kullanımını etkiler } \\
\text { mi? }\end{array}$} & Yanit & Evet & 11 & $\ddot{O}_{1,2, \ldots, 10,11}$ \\
\hline & Etki & Pozitif etki & 11 & $\begin{array}{l}\ddot{O}_{7}, \text {,..hoca kullandiğ zaman bende kullanmak isterim .... } \\
\text { açıçası teknoloji ile aram biraz kötü ama daha iyi } \\
\text { kullanmak isterdim." } \\
\ddot{O ̈}_{4} \text { “..teknoloji iyi kullanıldığında dikkat ve ilgi çekiyor. } \\
\text { Kullanılmadı̆̆ında dersten soğuma bile yapabiliyor." } \\
\ddot{O ̈}_{8} \text { "..öğretmenlik hayatım açısından olumlu etkiliyor. Ben } \\
\text { bunu ögrretmen olduğumda da kullanabilirim diyebiliyorum.", } \\
\text { "..hocalardan ilham alırız." }\end{array}$ \\
\hline
\end{tabular}

Diğer taraftan öğretmen adaylarının ifadelerine göre bir dersin içeriği oluşturulurken dikkate alması gereken kıstaslar yapılması gerekenler ve yapılmaması gerekenler teması altında toplanmıştır. Yapılması gerekenler teması görsellik ve ögretim teknolojilerinin tanıtımı alt temalarından oluşurken, Yapılmaması gerekenler teması salt sunumun terkedilmesi alt temasından oluşmaktadır. Görsellik alt teması bağlamında dersin teorik kısmının ardından pekişmesi veya zihinde daha iyi somutlaşması adına öğretme sürecinin çeşitli görseller ile desteklenmesi talep edilmiştir. Bu hususların daha dikkatli olarak organize edilmesinin, dersin verimliliği açısından daha faydalı olacağı ifade edilmiştir. Özellikle fen bilimleri dersinin, biyoloji konularında 3 boyutlu görsellerin (Artırılmış gerçeklik ve mobil 3 boyutlu uygulamalar), kimya konularında animasyon ve simülasyon gibi teknolojileri ders sirasında daha fazla kullanılarak derslerin işlenebileceği belirtilmiştir. Zira bazı fen konuları işlenirken görsel öğelerin olmaması neden-sonuç ilişkilerinin kurulmasını ve konunun zihinde yer edinmesini zorlaştırdığı ifade edilmiştir. Bu bağlamda ilgili konu kapsamında çeşitli öğretim teknolojilerinin tanıtımına da yer 
verilmesi gerektiği ve bu teknolojilerin öğretim sırasında nasıl kullanıldığı kendilerine gösterilmesi gerektiği ifade edilmiştir. Buna karşın salt sunumun terkedilmesi alt teması bağlamında birinci sınıf ögretmen adaylarının üçü, derste teknoloji kullanımını yalnızca projeksiyon cihazından yararlanmak olduğunu düşünmektedir. Dördüncü sınıf öğretmen adayları ise derslerde teknoloji kullanımının çok yetersiz olduğunu, PowerPoint kullanımının ise derste teknoloji kullanımı olarak kabul etmediklerini ifade etmiş̧lerdir. Bu bulguya dayanarak öğretmen adaylarında teknoloji kullanımına yönelik davranışsal eğilimin gelişmemesinde, öğretim üyelerinin derslerde teknolojiden yararlanmamasından kaynaklanabileceği düşünülmektedir.

Fen Bilimleri öğretmen adaylarına dersliklerin nasıl bir teknolojik alt yapıya sahip olması gerektiği sorusu yöneltilmiştir. Elde edilen cevaplar teknolojik sınıf teması altında toplanmıştır. Bu tema, Mobil telefon/tablet, akıllı tahta, bilgisayar ve çeşitli teknolojik ürün alt temaları altında toplanmıştır. Öğretmen adayları, fen bilimleri dersinin konularına bağlı olarak 3 boyutlu görsellerin, akıllı tahtaların, kişiye ait tablet ve bilgisayarların olması dersi daha eğlenceli ve etkili bir hale getireceğini düşünmektedir. Ayrıca öğrenme ortamlarında bilgisayarın ve günümüzde en sık kullanılan teknolojik cihazlardan olan telefonların öğretim sürecinde daha fazla yer almasının faydalı ve etkili olabileceği 4. sınıf öğretmen adayları tarafindan ifade edilmiştir. Birinci sınıf öğretmen adayları ise genellikle dersliklerde akıllı tahtaların olması yönünde bir beklenti içerisinde olduğu görülmektedir. Bu durum Fatih Projesi kapsamında yetişen ve ortaöğrenimini akıllı tahta ile yapan öğrenciler olmasından kaynaklandığı düşünülmektedir. Yine öğretmen adayları, dersliklerin sadece sıralar ile sınırlandırılmaması bununla yanında sıraların olmadığı bir teknoloji köşesine sahip sınıfın kurulabileceğini ifade etmişlerdir. Son olarak öğretim üyelerinin çeşitli teknolojik cihazların kullanması veya ders kapsamında tanıtılması öğretmen adaylarının ilgisini çektiği, bununla birlikte kendilerinin de öğrenmeye yönelik eğilimlerde bulunduğu ve gelecekte öğretmen olduğunda kullanabileceğini belirtmişlerdir.

Son olarak öğretim elemanlarının teknoloji becerileri, derslerde teknoloji kullanımını etkiler mi? sorusu yöneltilmiştir. Nitel bulgulardan elde edilen bulgulara göre öğretim görevli/üyesinin teknolojik beceriler sergilemesi veya ders sırasında kullanması öğretmen adaylarının tamamı tarafından olumlu yönde karşılanmaktadır. Diğer bir ifade ile ders sırasında çeşitli teknoloji ürünü veya teknolojinin bizzat kendisini kullanabilen öğretim görevli/üyesi, öğretmen adaylarına ilham kaynağı olmakla birlikte öğretmen adaylarının teknolojiye olan tutumunu da etkilediği düşünülmektedir. Hatta teknoloji kullanımında zorluk yaşayan bir öğretmen adayı, ders sorumlusunun teknolojiyi kullanması kendisine örnek olduğuna yönelik ifadeye rastlanılmıştır $\left(\ddot{\mathrm{O}}_{7}\right)$. Yükseköğretim sürecinde öğrenilen bu becerilerin gelecekte ögrretmenlik mesleğinde de kullanılacağı düşünülmektedir. Buna karşın dersin yalnızca projeksiyona bağlı olarak yürütülmesine ve projeksiyonda yaşanan teknik aksaklık durumunda dersin aksamasına karşı olumsuz tutum beslediği görülmüştür. Bu sebepten teknolojinin öğrenme ortamında kullanımı, öğretim üyelerinin yaşına bağlı olarak değişim göstermemesi, gerekirse bunun için hizmet içi eğitim veya seminerlere katılarak, ilgili dersin niteliğini arttıracak teknolojik ürünlerin sınıfa getirilmesi gerektiği ifade edilmiş̧ir. Bunun öğretmen eğitimi açısından da oldukça faydalı olacağı belirtilmiştir.

\section{Tartışma ve Sonuç}

$\mathrm{Bu}$ araştırma öğretmen adaylarının derste teknoloji kullanımına yönelik eğilimlerini hem nicel hem de nitel yaklaşımla ele almıştır. Araştırmadan elde edilen nicel bulgulara göre öğretmen adaylarının derste teknoloji kullanmaya yönelik eğilimlerin iyi seviyede olduğu belirlenmiştir. Ancak derste teknoloji kullanımına yönelik davranış eğilimi, duyuşsal eğilimin gerisinde kalmıştır. Diğer bir ifade ile fen bilimleri öğretmen adayları öğrenim gördüğü derslerde eğitim teknolojilerinin kendilerine daha iyi öğrenme, kalıcılık, öğrenmede kolaylık ve eğlenceli ders ortamı sağladığını düşünürken, teknoloji kullanılmasına katılım veya bu derslere hazırlıklı gidilmesine dönük davranışların aynı düzeyde sergilenmediği söylenebilir. Benzer şekilde Şahin ve Arslan-Namlı (2019), çeşitli branşlardan öğretmen adaylarının eğitimde teknoloji kullanımında kendini geliştirmeye yönelik davranışsal eğilimlerini orta düzey olduğunu saptamıştır. Son olarak özel eğitim, PDR, Sınıf ve okul öncesi öğretmen adaylarının eğitimde teknoloji kullanımına yönelik davranışsal eğilimi 3,37 ile duyuşsal eğilimin oldukça gerisinde kaldığ tespit edilmiştir Hursen (2017). Bu durum davranışsal eğilimlerinin gelişmesinden önce ön koşul olarak duyuşsal eğilimin gelişmesi gerektiği şeklinde açıklanmıştır (Günüç ve Kuzu, 2014). Ancak bilgi teknolojilerini derste kullanma davranışları meslek çevresinin kullanma eğilimlerine, sosyal çevrenin 
etkisine bağlı olduğu düşünülmektedir (Bunchanan, Sainter ve Saunders, 2013; Teo ve Noyes, 2014). Sonuç olarak her ne kadar öğretmen adaylarının derste teknoloji kullanımına yönelik duyuşsal yönü gelişmiş olursa olsun, teknolojinin birinci sınıftan dördüncü sınıfa kadar genellikle eğitsel amaçlı kullanılmaması (Kahraman, Yılmaz, Erkol, Altun Yalçın, 2013), sınıf düzeyinin derste teknoloji kullanımına yönelik davranışsal eğilimlerini de geliştirmediği söylenebilir.

Nitel bulgulara bakıldığında öğretmen adayları, derslerde teknolojiden daha fazla yararlanması, bu teknolojinin ise powerpoint sunumlarıyla sınırlı kalınmaması, bunun yanında fen eğitimi ile ilgili birçok konuya ilişkin kullanılabilecek teknolojik ürünlerin ya da programların sınıf ortamlarına getirilmesi gerektiğini belirtmişlerdir. Özellikle dördüncü sınıfta öğrenim gören öğretmen adaylarının, akıllı tahta kullanımını üniversitede öğretmen eğitiminin bir parçası olarak öğrenme talepleri yalnız bu çalışma kapsamında değil farklı çalışmalar kapsamında da (Baydaş ve Yılmaz, 2017; Korkmaz ve Korkmaz, 2015) ele alınmıştır. Çünkü Baydaş ve Yılmaz (2017)'ye göre öğretmen adaylarının gelecek mesleklerinde akıllı tahta kullanma eğilimi, kendi mesleki performansını arttıracağı görüşüne dayanmaktadır. Bunun yanında öğretim üyesi/görevlilerinin çeşitli teknolojilerden yeteri kadar faydalanmadıklarına yönelik ifadeleri, derste teknoloji kullanımına yönelik davranışsal eğilimin duygusal eğilime göre geride kalmasını açıklar niteliktedir. Zira öğretmenlik mesleğini icra edenlerin hizmet öncesi dönemlerinde kendilerine verilen yetersiz bilgi ve deneyimler, eğitimde teknoloji kullanımını engelleyen en büyük neden olduğu düşünülmektedir (Chai, Koh ve Tsai, 2010). Diğer taraftan öğretmen adaylarının arkadaş çevresinde yer alan kişilerin bilgi teknolojilerini kullanma eğilimleri, kendi eğilimlerini olumlu yönde etkilemektedir (Teo ve Noyes, 2014). Bu sebepten bu teknolojileri öğrenme ortamına taşıyan rol modellerin sayısında yaşanan artış, teknolojinin eğitime entegrasyonunu artıracağı düşünülmektedir.

Yine nitel bulgulara dayalı olarak öğretmen adaylarının (S6; $\left.\ddot{O}_{9}, \mathrm{O}_{10}\right)$ derste teknoloji kullanımına yönelik örnekleri sadece üniversite eğitimi kapsamında öğrenmelerinden, günlük yaşamlarında teknolojik yenilikleri tam olarak takip etmediği anlaşılmaktadır. Bu bakımdan öğretmen adaylarının da daha fazla davranışsal girişimlerde bulunması gerektiği düşünülmektedir. Çünkü öğretmen adaylarının teknoloji kullanımı; günlük yaşamda eğlence ve sosyal medya; öğretim bağlamında ise ödev hazırlama ve konu öğrenimi kapsamındaki videolar ile sınırlı kalmasından dolayı yeni teknolojilerin üretimi veya ders öğretimi sırasında hangi yeni teknolojilerin gelişim gösterdiğine yönelik araştırma girişimlerinin de olmadığı tespit edilmiştir. Bu durum öğretmen adaylarının eğitsel teknoloji kullanımına yönelik özyeterliliklerinin zayıf olmasından kaynaklı olabilir (Yenilmez, Turgut, Anapa ve Ersoy, 2011). Diğer taraftan öğretmen adaylarının bilişim teknolojilerini kullanabilme noktasında kendilerini söylem olarak yeterli gördüğünü ancak işe koşulma durumunda öğretim teknolojileri yerine gerçek deneysel etkinlikleri tercih etmesini özgüven ve deneyim eksikliğine dayandırılmıştır (Çelik ve Karamustafaoğlu, 2016). Cabi ve Ergün (2016) ise bu durumu öğretmen adaylarının BíT kullanımına yönelik kaygı düzeylerinin yüksek olmasına bağlamıştır. Nitel bulgulardan elde edilen bir diğer sonuca göre öğrenim görülen yerin sadece sıralardan ibaret olmaması gerektiği, bunun yanında teknolojik uygulamaların yapılabileceği bir köşe olması, öğretmen adaylarının ideal sınıf özelikleri arasında saymaktadır. $\mathrm{Bu}$ beklenti, McCrindle Research (2012)'ün kuşakların özelliklerini belirlediği araştırmada, z-kuşağına ait bireylerin öğrenme ortamlarını salon (lounge) tipi olması ile örtüşmektedir. Diğer bir ifade ile öğrenme, ilgili disiplinin doğasına uygun öğrenme köşelerinin olduğu bir sınıf tipi ön plana çıkmaya başlamaktadır.

Araştırmadan elde edilen bir diğer nicel bulgulara göre derste teknoloji kullanmaya yönelik eğilim sınıf düzeyi bağlamında ele alınmıştır. Buna göre 4. sınıf düzeyinde öğrenim gören fen bilimleri öğretmen adaylarının derste teknoloji kullanmaya yönelik genel ve duyuşsal eğilimleri, 1. sınıftakilere göre daha yüksektir. Nitel görüşmede ise dördüncü sınıf öğretmen adaylarının fen eğitiminde kullanılan teknoloji ürünlerine ya da programlarına daha çeşitli örnekler vermiş ve teknolojinin öğrenim üzerindeki birçok olumlu etkilerine değinmişlerdir. Bu durum, onların üniversite öğrenimi sırasında aldıkları öğretim ilke ve yöntemleri, materyal tasarımı ve özel öğretim yöntemleri gibi derslerin etkisinden kaynaklanabileceği düşünülmektedir.

Özetle, fen bilimleri öğretmen adaylarının fen dersinde teknolojinin kullanılmasına yönelik eğilimleri gerek nicel bulgular gerekse nitel bulgular ışığında bazı benzerlikleri ortaya çıkardığı görülmüştür. Teknolojinin konunun öğrenilmesi ve ödev hazırlanması durumunda kolaylık sağladığı, derslerde farklı teknolojilere yer verilmesi gerektiği, ödev/ders kapsamında teknoloji aracılığıyla arkadaşlarla iletişim kurulmasının keyif verdiği, teknolojinin kullanıldığı derslerin daha iyi takip edildiği gerek nitel görüşme 
bulguları gerekse nicel bulguları sonucunda ortaya çıkmıştır. Diğer taraftan nicel bulgulara göre derste teknoloji kullanılmasına yönelik duyuşsal eğilimin, davranışsal eğilimin önüne geçtiği belirlenmiştir. Nitekim bu durum öğretmen adaylarının farklı teknolojileri araştırıp öğrenme ortamına taşıma girişiminde bulunmaması ve teknolojik becerilerin zayıf olması şeklinde ifade edilen nitel bulgularla paralellik göstermektedir. Son olarak nitel bulgulara göre dördüncü sınıf öğrencileri, fen öğretiminde hangi teknolojinin kullanılabildiğine yönelik daha çeşitli ve doyurucu örnekler verirken, birinci sınıf ögrencileri ise yalnızca bilgisayar ve akıllı tahta ile sınırlı kaldığı görülmektedir. Bu durum nicel bulgular açısından da benzerlik göstermektedir. Bu çalışma uzaktan eğitimin henüz öğretimin merkezine alınmadığı Covid-19 pandemi süreci öncesinde yürütülmüştür. Bu sebepten öğretmen adaylarının derste teknoloji kullanımına ilişkin eğilimleri bu sınıllılıklar çerçevesinde ele alınmıştır. Araştırmadan elde edilen bulgular 1şı̆̆ında öğretmen adaylarının derste teknoloji kullanımına yönelik eğilimlerin arttırılmasında bazı öneriler verilmiștir:

$\checkmark \quad$ Fen bilimleri öğretmen adaylarının derste teknoloji kullanmaya yönelik eğilimleri, Covid-19 pandemi süreciyle birlikte büyük bir değişim içerisinde olacağı tahmin edilmektedir. $\mathrm{Bu}$ sebepten Covid-19 pandemi süreci çerçevesinde fen bilimleri öğretmen adaylarının derste teknoloji kullanımına yönelik eğilimleri yeniden ele alınabilir.

$\checkmark \quad$ Öğretmen adaylarının derste teknolojiye yönelik bir eğilime sahip olduğu ancak bu eğilimin davranışa dönüşmesi noktasında aksaklıkların olduğu ortaya çıkmıştır. $\mathrm{Bu}$ durumun hangi sebeplerden kaynaklandığına yönelik çalışmalar yapılabilir.

$\checkmark$ Çeşitli teknolojik ürün (robotik ve kodlama, Probe) veya program örneklerinin (mobil uygulamalar, artırılmış/sanal gerçeklik vb.) fen bilimleri dersi kazanımlarını destekleyebileceği daha sistematik olarak derleyen çalışmalar, öğretmen adaylarının derste teknoloji kullanımına yönelik davranışsal eğilimlerini artıracağı düşünülmektedir.

\section{Kaynakça}

Asan, A., \& Haliloğlu, Z. (2005). Implementing project based learning in computer classroom. The Turkish Online Journal of Educational Technology, 4(3), 68-81.

Aslan Efe, H., Oral, B., Efe, R. \& Öner Sünkür, M. (2011). The effects of teaching photosynthesis unit with computer simulation supported co-operative learning on retention and student attitude to biology. Necatibey Faculty of Education Electronic Journal of Science and Mathematics Education, 5(1), 313-329.

Başer, V. G., Mutlu, N., Şendurur, P. \& Şendurur, E. (2012). Öğrencilerin teknoloji entegrasyon algis1. Education Sciences, 7(2), 591-598.

Baydaş, Ö. \& Yılmaz, R. M. (2017). Öğretmen adaylarının gelecekteki derslerinde etkileşimli tahta kullanma niyetlerine yönelik model önerisi. Journal of Higher Education \& Science, 7(1), 5966.

Boonmoh, A., Jumpakate, T. \& Karplon (2021). Teachers' perceptions and experience in using technology for the classroom, Computer-Assisted Language Learning Electronic Journal (CALL-EJ), 22(1), 1-24.

Buchanan, T., Sainter, P., \& Saunders, G. (2013). Factors affecting faculty use of learning technologies: Implications for models of technology adoption. Journal of Computing in Higher Education, 25(1), 1-11.

Cabi, E. \& Ergün, E. (2016). The impact of instructional technologies and material development course on the teacher candidates' concern about using educational technologies, Baskent University Journal of Education, 3(1), 37-43.

Ceylan, R. \& Akçay, B. (2018). Bilgi ve İletişim Teknolojileri (BİT) okuryazarlığı, (Ed. Öğretir Özçelik, A., D. \& Tuğluk, M. N.), Eğitimde ve Endüstride 21. Yüzyll becerileri. Ankara: Pegem Akademi Yayıncilik.

Chai, C. S., Koh, J. H. L., \& Tsai, C. C. (2010). Facilitating preservice teachers' development of technological, pedagogical, and content knowledge (TPACK). Journal of Educational Technology \& Society, 13(4), 63-73.

Creswell, J. W. \& Plano Clark, V. L. (2015). Karma yöntem araştırmaları tasarımı ve yürütülmesi (Y. Dede ve S. B. Demir, Çev. Ed.). Ankara: Anı Yayıncılık 
Creswell, J.W. (2013). Research design: Qualitative, quantitative, and mixed methods approaches, Thousand Oaks, CA: Sage.

Çelik, C., Güven, G. \& Çakır, N. K. (2020). Integration of mobile augmented reality (mar) applications into biology laboratory: Anatomic structure of the heart. Research in Learning Technology, 28, $1-11$.

Çelik, H. \& Karamustafaoğlu, O. (2016). Science prospective teachers' self-efficacy and views on the use of information technologies in the teaching of physics concepts. Necatibey Faculty of Education Electronic Journal of Science and Mathematics Education, 10(1), 182-208.

Çetin, C. \& Karalar, S. (2016). X, Y ve Z kuşağı öğrencilerin çok yönlü ve sınırsız kariyer algıları üzerine bir araştırma. Yönetim Bilimleri Dergisi, 14(28), 157-197.

Çokluk, Ö., Şekercioğlu, G. \& Büyüköztürk, Ş. (2012). Sosyal bilimler için çok değişkenli istatistik SPSS ve LISREL uygulamaları, 2. Bask1, Ankara: Pegem Akademi Yayınc1lık.

Demirci Güler, M. P. ve Irmak, B. (2018). Fen eğitiminde teknoloji kullanımı üzerine yapılan çalışmaların içerik analizi. Ahi Evran Üniversitesi Kırşehir Eğitim Fakültesi Dergisi, 19(3), 2473-2496.

Durak, H., \& Seferoğlu, S. S. (2017). Öğretmenlerin teknoloji kullanım yeterliklerinde etkili olan faktörlerle ilgili bir inceleme. (Ed. B. Akkoyunlu, A. İşman ve H. F. Odabaş1), Eğitim teknolojileri okumaları 2017, (29. Bölüm, ss. 537-556). TOJET-The Turkish Online Journal of Educational Technology.

Günüç, S., \& Kuzu, A. (2014). Tendency scale for technology use in class: development, reliability and validity. Journal of Theory and Practice in Education, 10(4), 863-884.

Güven, G., Çakir, N. K, Sulun, Y. Cetin G. \& Güven, E. (2020) Arduino-assisted robotics coding applications integrated into the 5E learning model in science teaching. Journal of Research on Technology in Education, 52, 1-19.

Herdem, K., Aygün, H. \& Çinici, A. (2014). Sekizinci sınıf öğrencilerinin teknoloji algılarının çizdikleri karikatürler yoluyla incelenmesi. Amasya Üniversitesi Ĕ̈itim Fakültesi Dergisi, 3(2), 232-258.

Herro, D., Visser, R. \& Qian, M. (2021) Teacher educators' perspectives and practices towards the technology education technology competencies (TETCs), Technology, Pedagogy and Education, 30(3), 1-19.

Hursen, C. (2017). Determining candidate teachers' tendency to the use of technology. World Journal on Educational Technology: Current Issues. 9(4), 183-190.

Instefjord, E. \& Munthe, E. (2016). Preparing pre-service teachers to integrate technology: An analysis of the emphasis on digital competence in teacher education curricula. European Journal of Teacher Education, 39(1), 77-93.

Irmak, B. \& Demirci, Güler, M. P. (2018). Fen eğitiminde teknoloji kullanımı üzerine yapılan çalışmaların içerik analizi. Ahi Evran Üniversitesi Eğitim Fakültesi Dergisi, 19(3), 2473-2496.

Kahraman, S., Yılmaz, Z. A., Erkol, M., \& Altun Yalçın, S. (2013). Öğretmen adaylarının eğitsel internet kullanımı öz yeterlik inançlarının incelenmesi. Illkögretim Online, 12(4), 1000-1015.

Kalaycı, Ş. (2006). SPSS Uygulamalı Çok Değişkenli İstatistik Teknikleri. Ankara: Asil Yayın Dağıtım.

Kenar, İ. \& Balcı, M. (2013). Öğrencilerin derslerde teknoloji ürünü kullanımına yönelik tutumu: bir ölçek geliştirme çalışması. Mustafa Kemal Üniversitesi Sosyal Bilimler Enstitüsü Dergisi, $10(22), 249-262$.

Kolikant, Y. B. D. (2010). Digital natives, better learners? students' beliefs about how the internet influenced their ability to learn. Computers in Human Behavior, 26, 1384-1391.

Korkmaz, E. \& Korkmaz, C. (2015). Candidate teachers views towards the use of interactive board. Mustafa Kemal Üniversitesi Sosyal Bilimler Enstitüsü Dergisi, 12(32) , 477-497

Kurtoğlu, M., \& Seferoğlu, S.S. (2013). Öğretmenlerin teknoloji kullanımı ile ilgili Türkiye kaynaklı dergilerde yayımlanmış makalelerin incelenmesi. Journal of Instructional Technologies \& Teacher Education, 2(3), 1-10.

Lasserre-Cortez, S. (2006). A mixed methods examination of professional development through whole faculty study groups (Unpublished doctoral dissertation), Louisiana State University, Baton Rouge.

McCrindle Research (2012). Https://2qean3b1jjd1s87812ool5ji-Wpengine.Netdna-Ssl.Com/WpContent/Uploads/2018/03/Generations-Defined-Sociologically.Pdf 
Miles, M, B., \& Huberman, A. M. (1994). Qualitative data analysis: An expanded Sourcebook (2 nd ed.). Thousand Oaks, CA: Sage.

Millî Eğitim Bakanlığı [MEB] (2018a). Güçlü yarınlar için 2023 eğitim vizyonu. Ankara: MEB. Retrieved from http://2023vizyonu. Meb.gov.tr/doc/2023_EGITIM_VIZYONU.pdf

Milli Eğitim Bakanlı̆̆ [MEB] (2018b). Fen bilimleri dersi öğretim programı (ilkokul ve ortaokul 3, 4, $5,6,7$ ve 8 . Sinıflar) öğretim programı. Ankara: Devlet Kitapları Basımevi.

Öğretir Özçelik, A. D. (2018). İnovasyon, Yaratıcılık ve Yenilenme. (Ed. Öğretir Özçelik, A., D. \& Tuğluk, M. N.). Eğitimde ve Endüstride 21. Yüzyll becerileri. Ankara: Pegem akademi yayincilik.

Özmen, H. \& Kolomuç, A. (2004). Bilgisayarlı öğretimin çözeltiler konusundaki öğrenci başarısına etkisi, Kastamonu Eğitim Dergisi, 12(1), 57-68.

Parasnis, I., Samar, V. J., \& Fischer, S. D. (2005). Deaf college students' attitudes toward racial/ethnic diversity, campus climate, and role models. American Annals of the Deaf, 150(1), 47-58.

Parker, R. E., Bianchi, A. \& Cheah, T. Y. (2008). Perceptions of instructional technology: Factors of influence and anticipated consequences. Educational Technology \& Society, 11(2), 274-293.

Pedró, F. (2006). The new millennium learners: Challenging our views on ICT and learning. Paris: OECD-CERI.

Pekdağ, B. (2010). Kimya öğreniminde alternatif yollar: animasyon, simülasyon, video ve multimedya ile öğrenme. Journal of Turkısh Science Education, 7(2), 79-110.

Şahin, M. C. \& Arslan-Namlı, N. (2019). Öğretmen adaylarının eğitimde teknoloji kullanma tutumlarının incelenmesi. Türkiye Sosyal Araştırmalar Dergisi, 23(1), 95-112.

Tanık Önal, N. (2017). Bilgi ve iletişim teknolojileri kullanımı: Fen bilgisi öğretmen adaylarının görüşleri. International Journal of Active Learning, 2(1), 1-21.

Teo, T. \& Noyes, J. (2014). Explaining the intention to use technology among pre-service teachers: A multi-group analysis of the unified theory of acceptance and use of technology. Interactive Learning Environments, 22( 1), 51-66.

Wojciechowski, R. \& Cellary, W. (2013). Evaluation of learners' attitude toward learning in ARIES augmented reality environments. Computers \& Education, 68, 570-585.

Yazzie-Mintz, E. (2010). Charting the path from engage-ment to achievement: A report on the 2009 high school survey of student engagement. Bloomington, IN: Center for Evaluation \& Education Policy.

Yenice, N., Candarlı, F., Yavaşoğlu, N. \& Alpak Tunç, G. (2019). The use of communication technology by pre-service science teachers in the scientific process. Sakarya University Journal of Education, 9(1), 33-46.

Yenilmez, K., Turgut, M., Anapa, P. \& Ersoy, M. (2011). İlköğretim matematik öğretmeni adaylarının eğitsel internet kullanımına yönelik öz-yeterlik inançları. 5. Uluslararası Bilgisayar ve Öğretim Teknolojileri Sempozyumu Bildiriler Kitabı (s. 463-468). Firat Üniversitesi.

Yılmaz, M. (2016). İlkokul Öğretmenlerinin eğitimde teknoloji kullanımına ilişkin bilgisayar yeterliliklerinin ve teknoloji tutumlarının değerlendirilmesi (Yayınlanmamış Yüksek Lisans Tezi). Mersin Üniversitesi, Mersin.

Yılmaz, Z. A. \& Batdı, V. (2016). Artırılmış gerçeklik uygulamalarının eğitimle bütünleştirilmesinin meta-analitik ve tematik karşılaştırmalı analizi. Ĕ̈itim ve Bilim, 41(188), 273-289.

\section{EXTENDED SUMMARY}

\section{Introduction}

The advent of technology, which started with the discovery of fire, wheel and writing, has been continuously changing and developing to the present day with the increasing needs and accumulation of scientific knowledge. Today, human life cannot be taught of as an independent body of technology. It seems that human beings do not have a single day spent without using any product of technology. In this respect, technology, which is a product of scientific activities and facilitates the lives of people, makes its impact felt in every aspect of life today. One of these aspects is education. Some subjects in science courses (DNA, atomic structure, molecule, space, sensory organs, magnetic field, etc.) (MEB, 
2018b), unless supported by various technological devices or programs, remain abstract in minds of preservice teachers or students (Pekdağ, 2010; Aslan Efe, Oral, Efe and Öner Sünkür, 2011).

\section{Method}

In this regard, the current study aimed to investigate the pre-service teachers' tendencies towards using technology in class. The study employed the convergent parallel mixed design, one of the mixed method designs. The study group of the quantitative part of the current research consists of 88 students attending the Department of Science Teacher Education while the study group of the qualitative part consists of 11 pre-service teachers ( 6 first-year students, 5 fourth-year students) selected from the 88 students. The quantitative data were collected with the Scale of Tendency Towards Using Technology in Class while the qualitative data were collected with semi-structured interviews conducted with 6 first-year students ( 2 females, 4 males) and 5 fourth-year students (4 females, 1 male).

\section{Findings, Discussion and Results}

According to the quantitative data, the pre-service teachers' mean score of tendency towards technology was calculated as 3.97. The mean scores found for the sub-dimensions of behavioural tendency and affective tendency are 3.81 and 4.04, respectively. In light of these findings, it can be argued that the pre-service teachers' tendency towards using technology in class is at the good level and their behavioural tendency falls behind their emotional tendency. The mean score of emotional tendency towards using technology in class was found as 3.76 for the first-year students and 4.17 for the fourthyear students. The mean score of behavioural tendency was found as 3.63 for the first-year students and 3.89 for the fourth-year students. For the whole scale, the mean score of tendency towards using technology in class was found as 3.72 for the first-year students and 4.09 for the fourth-year students. Dependent samples t-test was conducted to determine whether the mean scores taken from the whole scale and its sub-dimensions vary significantly depending on grade level. As a result, it was concluded that while the emotional tendency mean score varies significantly depending on grade level in favour of the fourth-grade students, the behavioural tendency mean score does not vary significantly depending on grade level.

The qualitative findings have revealed that the pre-service teachers are of the opinion that technology is a product of scientific activities and facilitates our daily lives. They stated that they generally use technology to spend a good time in social media. They also stated that in their student life, they use technology to better learn their subjects through audio-visual elements it provides, to prepare presentations in their classes, to do some inquiries for their homework and to share data. However, it was observed that they did not invest any efforts to use any different technologies for the preparation or presentation of their homework. ${ }^{\mathrm{i}}$

\footnotetext{
${ }^{\mathrm{i}} \mathrm{Bu}$ araştırmaya yazarlar eşit oranda katkı sağlamıştır.
} 